\title{
Team-Based Learning methodology applied to the construction of a child delivery plan model
}

\author{
Metodologia Team-Based Learning aplicada à construção de um modelo de plano de parto \\ Metodología Team-Based Learning aplicada a la construcción de un modelo de plan de parto
}

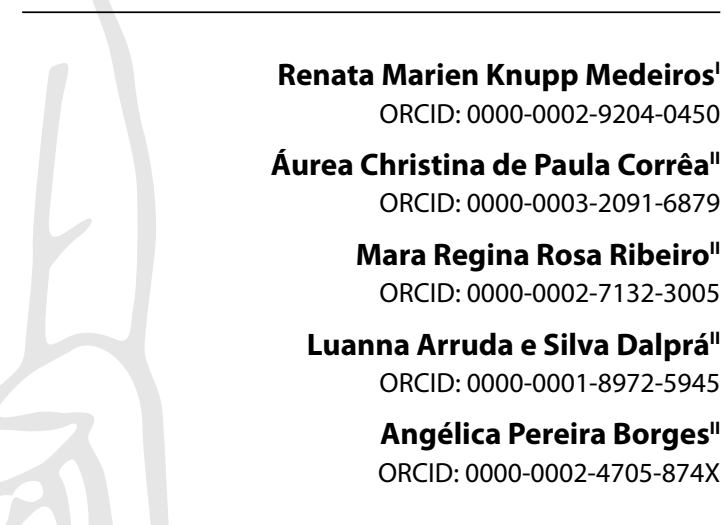

'Universidade Federal de Rondonópolis. Rondonópolis, Mato Grosso, Brazil.

"Universidade Federal de Mato Grosso. Cuiabá, Mato Grosso, Brazil.

How to cite this article: Medeiros RMK, Corrêa ACP, Ribeiro MRR, Dalprá LAS, Borges AP. Team-Based Learning methodology applied to the construction of a child delivery plan model. Rev Bras Enferm. 2021;74(6):e20190910. https://doi.org/10.1590/0034-7167-2019-0910

Corresponding author: Renata Marien Knupp Medeiros E-mail: renata.knupp@ufr.edu.br

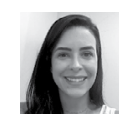

EDITOR IN CHIEF: Antonio José de Almeida Filho ASSOCIATE EDITOR: Maria Elisabete Salvador

Submission: 12-26-2019

Approval: 03-13-2021

\section{ABSTRACT}

Objective: to report an experience using the Team-Based Learning methodology for the development of a standard model for Birth Plans by health professionals. Methods: experience report on the use of Team-Based Learning to develop care technology, with the participation of 120 professionals from two municipalities located in the Midwest Region. Results: the use of Team-Based Learning in this experience enabled the construction of a Child Delivery Plan model based on the theoretical approach to the theme, a critical reflection exercise, an in-depth discussion, decision-making, after what a consensus was reached. The methodology enabled the (co) construction of knowledge in small groups, teamwork, accountability, and satisfaction among the participants. Final Considerations: the use of the TeamBased Learning methodology proved to be effective as a discussion strategy, building consensus and syntheses for the elaboration of a care technology aimed at the pregnancy-parturition period.

Descriptors: Biomedical Technology; Learning; Health Education; Reproductive Health; Humanizing Delivery.

\section{RESUMO}

Objetivo: relatar a experiência com o uso da metodologia Team-Based Learning para a elaboração de um modelo-padrão de Plano de Parto por profissionais de saúde. Métodos: relato de experiência sobre o uso do Team-Based Learning para elaboração de uma tecnologia de cuidado, com a participação de 120 profissionais de dois municípios localizados na Região Centro-Oeste. Resultados: o uso do Team-Based Learning nesta experiência possibilitou a construção de um modelo de Plano de Parto com base na aproximação teórica com a temática, exercício crítico de reflexão, discussão em profundidade, tomada de decisões e consensos. A metodologia fomentou a (co) construção de conhecimentos em pequenos grupos, trabalho em equipe, responsabilização e satisfação entre os participantes. Considerações Finais: o uso da metodologia TeamBased Learning mostrou-se eficaz como estratégia de discussão, construção de consensos e sínteses para elaboração de uma tecnologia de cuidado voltada ao período gravídico-parturitivo. Descritores: Tecnologia em Saúde; Aprendizagem; Educação em Saúde; Saúde Reprodutiva; Parto Humanizado.

\section{RESUMEN}

Objetivo: relatar la experiencia con el uso de la metodología Team-Based Learning para la elaboración de un modelo-estándar de Plan de Parto por profesionales de salud. Métodos: relato de experiencia sobre el uso del Team-Based Learning para elaboración de una tecnología de cuidado, con la participación de 120 profesionales de dos municipios localizados en la Región Medio Oeste. Resultados: el uso del Team-Based Learning en esta experiencia posibilitó la construcción de un modelo de Plan de Parto con base en el acercamiento teórico con la temática, ejercicio crítico de reflexión, discusión en profundidad, toma de decisiones y consensos. La metodología fomentó la (co)construcción de conocimientos en pequeños equipos, trabajo en equipo, responsabilización y satisfacción entre los participantes. Consideraciones Finales: el uso de la metodología Team-Based Learning mostró eficaz como estrategia de discusión, construcción de consensos y síntesis para elaboración de una tecnología de cuidado vuelta al período puerperio.

Descriptores: Tecnología Biomédica; Aprendizaje; Educación en Salud; Salud Reproductiva; Parto Humanizado. 


\section{INTRODUCTION}

The use of active teaching-learning methodologies has been more frequent in health education as it is consistent with the desired professional profile for the area. The potential of this strategy is related to the development of skills that enable the empowerment of the subject to solve problems, overcome challenges and implement changes in health paradigms. The benefits of active methodologies include the development of student autonomy by breaking with the traditional educational model, encouraging critical reflection, the integration between theory and practice and the collective and dialogical construction of knowledge $\mathrm{e}^{(1)}$.

In this context, Team-Based Learning (TBL) is an active methodology, which is characterized mainly by requiring the student's active participation and collaboration through team performance. This process facilitates the acquisition of a common and complete understanding among the group members, as they progress in the discussion. Ensuring that the lack of understanding of certain content at the individual level is achieved in peer learning ${ }^{(2)}$.

TBL emerged in the late 1970s, in the United States, due to the need for a teacher to work with a class of 120 students. In the process of applying the methodology, the potential to promote student satisfaction, motivation and accountability for the learning process was observed, together with the improvement in critical reasoning and decision-making. In 2001, TBL started to be used in health education, in particular, for developing skills to work as a team, as well as for multiprofessional involvement in the construction of strategies that improve the quality of service ${ }^{(3-4)}$.

TBL promotes strong pedagogical benefits for health education and is related to greater responsibility and student satisfaction, when compared to standard teaching methods such as traditional classes ${ }^{(5)}$. As it is a methodology that is developed in teams, TBL has been an alternative for working with large groups, in order to promote knowledge through meaningful learning ${ }^{(3)}$. Although carried out with numerous participants, it respects a principle of active methodologies, as it develops through the formation of several smaller, in which the construction of knowledge takes place.

In addition to promoting meaningful learning by enabling collaborative and effective teamwork, TBL also allows decision making and consensus, the involvement and active participation of heterogeneous groups, and also facilitates the construction of knowledge on a given topic. Furthermore, the methodology is able to subsidize the production of knowledge in several areas that seek the active and reflective performance of the participants, since it is based on the theory of constructivism, which proposes the construction of learning through argumentative dialogue and interaction among team members, with repercussions on the formation of critical reasoning ${ }^{(3)}$.

Considering the potentialities of TBL in the teaching-learning process and the need to contribute to the qualification of reproductive health care, the innovative construction of a care technology aimed at the pregnant-parturitive period was proposed. This technology was called the Birth Plan, and it involved different actors (nursing students, research professors, and health professionals) from different settings.

Birth Plans are legal documents that allow women to register, throughout pregnancy, preferences, expectations and individual needs related to their labor, delivery, and the birth of their child ${ }^{(6)}$. Among the functions of a Birth Plan, three stand out: 1) to promote health education, since this instrument can be used as a guide by professionals in Primary Care in the preparation of women for childbirth; 2) encourage pregnant women to seek information to make choices and prepare for this experience in an active and participatory way; 3 ) allowing women to communicate their preferences in writing to the hospital health team ${ }^{(7)}$.

Despite being a low-cost technology, easy to use and with benefits recognized for some years, there are obstacles to the implementation of the Birth Plan in different realities ${ }^{(7)}$. Such difficulties are partly related to the lack of knowledge of this tool by pregnant women / parturients ${ }^{(8)}$, as well as the lack of clarity of health professionals about its purpose and benefits ${ }^{(7)}$. In the Brazilian context, positive initiatives with the use of the Birth Plan are observed in services that have implemented it as a routine, such as delivery centers ${ }^{(8)}$. In this context, it is understood that caregivers involved with prenatal care need to be trained, encouraged, and supported in the incorporation of the Birth Plan in the different services.

Another possible barrier related to the non-use of the Birth Plan is the insufficiency of models of this instrument accessible to women, which, although available on the internet ${ }^{(9)}$, are generic and do not consider the reality of the different health services. In this sense, standardized Birth Plans, designed based on regional specificities, can give women the opportunity to outline their preferences, based on resources, methods, and techniques available in specific physical facilities, thus avoiding the creation of unrealistic expectations, that can generate frustrations ${ }^{(7)}$.

Considering the limited use of active methodologies in the development of health technologies and aiming to provide a decentralized, participatory, and coherent construction with the specificities of the obstetric care network of a Brazilian region, the TBL was chosen as a resource for the elaboration of an instrument of care to the pregnant-parturitive period that met local needs.

In view of the above, the following question emerged: IS TBL configured as an effective methodology for the collaborative construction of health technologies?

\section{OBJECTIVES}

To report the experience with the use of the TBL methodology for the elaboration of a standard model for a Birth Plan by health professionals.

\section{ACTIVITIES DESCRIPTION}

Taking into account the recognized benefits of the Birth Plan and the reduced use of this technology by Brazilian pregnant women, especially SUS users, six research professors associated to the graduation and post-graduation courses in Nursing took action aimed at intervening in this problem at the local level. The proposition consisted in the elaboration of a standard model for the Birth Plan that was consistent with the reality of health services and their users, in order to increase the use of this technology by pregnant women and encourage the support of professionals to use it. 
In view of the expertise of one of the researchers with the use of TBL, mainly in the field of education, this methodology was proposed for the collective and participative construction of the Birth Plan with professionals from the region's health network. Considering this, the activity planning began through three meetings, which made it possible to prepare the proposal; the definition of objectives, participants, date, place and duration of the activity; and the construction of the necessary tools for the development and evaluation of such an activity.

The methodology was applied in the context of a specialization course in reproductive health aimed at Primary Care professionals from two municipalities located in the Midwest Region, promoted by the Improvement and Innovation in Care and Teaching in Obstetrics and Neonatology (Apice On) project. This project consists of an initiative by the Ministry of Health, which, together with partner institutions, proposed the qualification of professionals in childbirth and birth; reproductive planning; attention to women in situations of sexual violence, abortion and legal abortion; and in teaching and university hospitals.

The action described in this research was carried out in 2018, in the auditorium of two teaching hospitals. 120 professionals participated and were divided into two groups of approximately 60 participants each. The activity was carried out with each group in a single session, lasting four hours, and was mostly attended by nurses, although there were also social workers (2), psychologists (3), graduation nursing students (6), among other professionals.

The development of the activity followed the steps proposed by the TBL method and started with the preparation of the participants, by making available to them a scientific article ${ }^{(6)}$, sent by e-mail prior to the face-to-face activity. The reading recommendation aimed to contextualize the theme and provide a basis for resolving the issues that would be explored in the next phase.

The face-to-face activity started with the presentation of the proposal by the moderator and a general explanation about the TBL. The activity continued by determining the professional education and function performed by each participant in the daily work, with the aim of organizing heterogeneous and multiprofessional teams, favoring the exchange of knowledge and experiences in the discussion of the theme proposed. With the exception of one team, all had the participation of an obstetric nurse working in hospital care. The teams were formed through the strategic distribution of flags of different colors, so that each subgroup was composed of seven participants. The infrastructure and the mobility of the chairs allowed the each team to form a circle.

After each team defined its self-designation, which allowed the creation of a group identity and facilitated the process of identifying the teams, the second stage, called "guarantee of preparation", began. At that moment, each participant was given a question book preceded by a brief text, prepared by the executive team based on scientific evidence, which aimed to summarize in simple language important aspects of the Birth Plan, such as: definition, history, indications, how to use it, advantages of use and recommendations of national and international public policies. After a silent and attentive reading, the participants answered individually to six multiple-choice questions with four alternatives each. The questions sought to identify the professionals' perception of the best format for the Birth Plan, considering the layout up to the items to be covered by the instrument.
During this individual stage, great commitment and interest from the participants was observed, which contributed to the involvement in the next phase, when each question was carefully discussed in small groups, so that the teams could, in consensus, choose the most appropriate answer for each item. This activity provided greater contact between the participants of the same team, allowing the individual expression of responses and arguments about the reasons for choosing a given option.

Among the teams that counted on the presence of obstetric nurses, more heated discussions were noted, as these specialists elucidated the hospital reality, often opposing individual choices that were not in accordance with the daily routine of local maternity services, generating rich dialogues and debates. In this context, the presence of the specialist nurse on the team was important to encourage argumentation and critical reflection among peers. However, at times, the figure of the professional inhibited the active participation of team members.

The enthusiastic discussions established in the small groups made possible: the exchange of knowledge between professionals working in different contexts; a better understanding of the care networks for pregnancy, childbirth and delivery; reassignment of good childbirth care practices; update on scientific evidence in the field of obstetrics and the rights of pregnant women / parturients; incorporation of previously unknown technical terms and changes in opinions regarding humanized care for women during childbirth.

After the discussions in the small groups were concluded, the support team collected the responses of each team; and, with the aid of the software Microsoft Excel, the prevalence of each answer was calculated, representing them in the form of graphs. From then on, an appeals process began in which the participants defended the arguments of their teams to the large group.

The moderator conducted this step so that each question was debated individually, after the projection of each item. After reading the question aloud, the teams raised signs in line with the consensual responses in the small groups; and then, a graph with the percentage of the indicated alternatives was made for everyone to see, showing the diversity of opinions between the teams.

During the appeal, team members engaged in dialogue in order to provide evidence-based argumentation / empirical and scientific references, to prove choices and to convince the group of the adequacy of their responses. At that moment, it was possible to have an overview of the concepts acquired by the participants and those that still needed clarification. Then, a member of the executing team, expert in the theme, would enter the scene to make a brief review of the issue under discussion, anchored in scientific literature, to clarify matters that had not yet been well understood.

After the expert's explanations, the large group showed greater security and knowledge to validate the answer deemed pertinent to each question, considering the local reality. After the consensus of all items was finalized, participants had an idea about what the final structure of the Birth Plan model would look like and could understand the relevant contributions of the group to the elaboration of this technology. It is worth mentioning that, at the beginning of the activity, most professionals were unaware of the Birth Plan, but, at the end of it, admitted that it was important for the implementation of humanized and qualified obstetric care for 
women, in addition to recognizing themselves as strategic actors in the use of this technology in their municipalities.

At the end of the TBL, the participants were invited to evaluate the activity performed, in particular, the methodology used for the preparation of the Birth Plan. Satisfaction with the experience was prevalent among the participants, who demonstrated active involvement throughout the process. The moderator ended by thanking everyone for their participation and clarifying the group about the necessary referrals for the approval and implementation of this model of Birth Plan in the health services of the municipalities involved.

After the closure of activities, the coordinating team consolidated the consensus, creating a semi-structured Birth Plan model, with the presence of illustrative images and questions that addressed the woman's preferences regarding the environment during labor; obstetric interventions; non-invasive technologies for pain relief; childbirth positions; newborn care; and their choices in case of cesarean sections. The instrument was sent to the secretariats and municipal health councils for consideration and approval.

\section{DISCUSSION}

The reported experience highlights TBL as a powerful learning methodology, since it required professionals to actively participate in all stages of the proposed activity, providing theoretical approach to the theme, the exercise of critical reflection, in-depth discussion, and decision-making actions.

Recent studies ${ }^{(2,5)}$ discuss the benefits of using TBL in health education, mainly because it is a methodology that requires greater involvement and participation of the student, in addition to providing problem solving capacity and superior academic performance, thus increasing its use in graduation courses in Medicine and Nursing ${ }^{(5)}$.

TBL confers strong pedagogical benefits to the learning of those involved, mainly by providing integration between theory and practice, making the training process more solid, coherent, and effective, enabling "meaningful learning". The association with reality as well as the valorization of previous and empirical knowledge facilitate the assimilation of contents, since they gain meaning and strength, promoting the development of critical thinking ${ }^{(1)}$.

In the present study, the relation of the theme discussed in the TBL with the situations faced by the participants in the daily practice of professional practice aroused interest and contributed to the involvement of the group, which frequently guided the arguments in the experienced work reality. Thus, previous experiences functioned as a base for the construction of new knowledge, especially those about the Birth Plan and the Good Practices of care during childbirth and birth. In the debates established in small and large groups, participants were able to learn about care technologies available to parturients, critically analyze each possibility and, based on the organizational context of hospital services, define the content to be included in the instrument.

This movement provided the instrumentalization of the group for the later use of the Birth Plan as an educational tool for pregnant women in professional practice, since this instrument is configured as a guiding script for discussion between women and professionals, thus, assisting in health education during the gestational period and in promoting shared decisions during labor ${ }^{(7)}$.
The effective exchange of knowledge in / between teams, especially heterogeneous ones, gives rise to significant contributions to the process of building knowledge with TBL. In addition, during teamwork, the participant must learn to respect different opinions and experiences in the process of collaboration with colleagues from different areas of professional training, aiming at the success of the teaching-learning process $^{(3)}$.

As evidence of this statement, a study that sought to examine the effects of interprofessional team learning with graduation nursing students concluded that TBL improves interdisciplinary work, quality of care and patient outcomes, which makes this work crucial in contemporary health systems ${ }^{(2)}$. The ability to work in a team makes it possible to learn effective interprofessional collaborative work skills, to understand their own professional role and understand the roles of other professions, in addition to providing a climate of mutual respect and sharing of values in order to provide patient-centered care, based on their needs ${ }^{(10)}$.

In this context, it is observed that the TBL activity allowed participants to understand the importance of teamwork in obstetric clinical practice, specifically with regard to the use of the Birth Plan, since the use of this instrument starts in Primary Care, with the support of professionals linked to prenatal care and, subsequently, it is continued by the hospital team, as a guide for the care of parturient women. Thus, the exchange of knowledge between professionals of different levels of care has made significant contributions to the process of building knowledge on the topic and improving collaborative teamwork.

Within this perspective, a study ${ }^{(5)}$ that sought to evaluate the use of TBL in the teaching of applied pathophysiology to graduation nursing students identified that the majority of students perceived a clear association between TBL activities and their own work experiences in team in clinical practice. The students recognized that the decisions made for patient care, in general, are better when performed by a team, and this was confirmed with the experiences of teamwork in clinical practice. Such evidence confirms the importance of encouraging students and professionals to be not only safe and competent nurses, but also effective members of the health team ${ }^{(5)}$.

Given the relevance of teamwork, it is important, in activities that use TBL as a methodology, to reduce any limitations to group cohesion, such as: affective bonds, different levels of know-how among participants, and others. Thus, the organizing committee must provide the distribution of participants aiming at diversity ${ }^{(3)}$. To this end, authors ${ }^{(3-4)}$ suggest that the subgroups should be randomly or intentionally divided to ensure that friendships or previously established relationships do not hinder group unity and decision making. Thus, heterogeneity guarantees a better performance of the participants.

In the experience reported in this study, diversity in the formation of teams was prioritized, and the interference generated by the presence of obstetric nurses in the group dynamics was notorious. These specialists sometimes stimulated discussions in small groups, explaining the practices of care for births and deliveries based on scientific evidence, but sometimes inhibited the participation of some members, especially those who did not have deep knowledge about the theme. However, it is understood that, in general, the participation of experts was positive in boosting 
the practice of critical reasoning, enriching the discussion and the creating a dynamic and motivating environment.

Another important aspect to be highlighted from the experience refers to the greater accountability promoted by the TBL, when compared to traditional teaching methods ${ }^{(5)}$. In their education, students should be encouraged to take responsibility for the construction of knowledge since they need to understand that the application of this knowledge will be essential in their future ${ }^{(3)}$, however, it is necessary to recognize that traditional education has not contributed to the expansion of autonomy and student accountability. In this context, the TBL is perceived as a potent active methodology that promotes accountability as it reaffirms the active role of the participants, treating them as protagonists in the management of their learning, which does not mean making them responsible or disregarding the existence of sociocultural limits.

The results with the use of the TBL indicate that the participants consider themselves more responsible when in group, since they get used to individual preparation, even when not related to TBL activities. This perceived responsibility was confirmed in focus group discussions, in which students frequently reported that preparation was essential for a meaningful and fair contribution to the group, in addition to being seen as a prerequisite for making the most of individual activities during TBL. Such results reinforce some of the benefits of TBL achieved through the emphasis on working in small groups ${ }^{(5)}$.

In the present study, in addition to the individual preparation that showed maturity and responsibility in relation to the construction of knowledge, the participants assumed together the responsibility of elaborating of an instrument that would contribute to the group's work process. The professionals were involved throughout the proposed activity, which enabled analysis, evaluation, and creativity to define the model of the Birth Plan.

In addition to the advantages noted earlier, the participants of this study showed satisfaction with the team learning provided by TBL. This confirms studies that show students' satisfaction with the methodology $y^{(3,5)}$ and a preference for this method compared to traditional classes. High levels of satisfaction with the TBL were reported even when the content covered was not considered interesting by the students.

What stands out in relation to the methodology adopted in this experience is that, in addition to meaningful learning, encouraging teamwork, accountability and satisfaction, TBL allowed the collective / collaborative construction of care technology based on the formulation of consensus in large groups. In addition, the activity provided to the participants a sense of protagonism and belonging to the group that created the model of the Birth Plan, with positive effects on professional self-esteem and encouragement for the implementation of the instrument in the Health Care Network.

\section{Study limitations}

The study had as a limitation the fact that no physicians participated, neither did professionals from other maternity hospitals in the municipalities involved, nor from other university hospitals not linked to Apice On.

\section{Contributions to the fields of nursing and education in health}

This study is one of the first to integrate TBL into the construction of a care technology aimed at reproductive health, contributing to the free and informed choice of pregnant women during the prenatal period and guaranteeing their preferences in the parturition process.

Thus, with this experience, nurses and researchers should be inspired to incorporate TBL in investigations that go beyond the field of teaching, in order to consider innovative and creative possibilities such as the construction of care technologies that aim to subsidize / qualify the work of the nurse through the active participation of these professionals.

With regard to health education, TBL proved to be a strategic resource to promote meaningful individual and group learning. In addition, it gives strong benefits to learning, promotes greater accountability and satisfaction of the participants.

\section{FINAL CONSIDERATIONS}

This study aimed to report the experience of using TBL as a support for the development of a standard model for Birth Plan by health professionals. It was found that the strategy used was effective in identifying and systematizing consensuses with a collaborative construction of technology, in addition to promoting learning about the Birth Plan and updating professionals about Good Practices in childbirth and birth care, giving them the instruments needed to use this technology in the daily routine.

At the same time, the TBL provided an understanding of the importance of teamwork in clinical practice in obstetrics, the link between Primary and Tertiary Care, as well as the different realities and needs faced by professionals in the same location, generally unknown due to the distance between these different levels of health care. The use of this methodology provided professional qualification through critical reflection, development of technology and consensus on its use in different realities.

\section{FUNDING}

We are thankful to the Coordination for the Improvement of Higher Education Personnel - Brazil (CAPES), for granting a scholarship under its Programa Prodoutoral (Pro-doctoral Program).

\section{REFERENCES}

1. Paiva MRF, Parente JRF, Brandão IR, Queiroz AHB. Metodologias ativas de ensino-aprendizagem: revisão integrativa. SANARE Rev Pol Públicas [Internet]. 2016 [cited 2019 Jun 20];15(2):145-53. Available from: https://sanare.emnuvens.com.br/sanare/article/view/1049/595

2. Wong AKC, Wong FKY, Chan LK, Chan N, Ganotice FA, Ho J. The effect of interprofessional team-based learning among nursing students: a quasi-experimental study. Nurse Educ Today [Internet]. 2017 [cited 2019 Jun 20];53:13-8. Available from: https://www.sciencedirect.com/ science/article/abs/pii/S0260691717300588?via\%3Dihub 
3. Krug RDR, Vieira MSM, Maciel MVDA, Erdmann TR, Vieira FCDF, Koch MC, et al. The "Bê-Á-Bá" of Team-Based Learning. Rev Bras Educ Méd [Internet]. 2016 [cited 2019 Jun 20];40(4):602-610. Available from: http://www.scielo.br/pdf/rbem/v40n4/1981-5271-rbem-40-4-0602.pdf

4. Searle NS, Haidet P, Kelly PA, Schneider VF, Seidel CL, Richards BF. Team learning in medical education: initial experiences at ten institutions. Acad Med [Internet]. 2003 [cited 2019 Jun 20];78(10):S55-S8. Available from: https://www.ncbi.nlm.nih.gov/pubmed/14557096

5. Branney J, Priego-Hernández J. A mixed methods evaluation of team-based learning for applied pathophysiology in undergraduate nursing education. Nurse Educ Today [Internet]. 2018 [cited 2019 Jun 20];61:127-33. Available from: https://www.sciencedirect.com/science/article/ pii/S026069171730268X?via\%3Dihub

6. Suárez-Cortés M, Armero-Barranco D, Canteras-Jordana M, Martínez-Roche ME. Use and influence of Delivery and Birth Plans in the humanizing delivery process. Rev Latino- Am Enfermagem [Internet]. 2015 [cited 2019 Jun 20];23 (3):520-526. Available from: http://www. scielo.br/pdf/rlae/v23n3/pt_0104-1169-rlae-0067-2583.pdf

7. Medeiros RMK, Figueiredo G, Correa ACP, Barbieri M. Repercussões da utilização do plano de parto no processo de parturição. Rev Gaúcha Enferm [Internet]. 2019 [cited 2019 Jun 20];40:e20180233. Available from: http://www.scielo.br/pdf/rgenf/v40/1983-1447-rgenf40-e20180233.pdf

8. Mouta RJO, Silva TMA, Melo PTS, Lopes NS, Moreira VA. Plano de parto como estratégia de empoderamento feminino. Rev Baiana Enferm [Internet]. 2017 [cited 2019 Jun 20];31(4):e20275. Available from: https://portalseer.ufba.br/index.php/enfermagem/article/ view/20275/15372

9. Anderson CM, Monardo R, Soon R, Lum J, Tschann M, Kaneshiro B. Patient communication, satisfaction, and trust before and after use of a Standardized Birth Plan. Hawaii J Med Public Health [Internet]. 2017 [cited 2019 Jun 20];76 (11):305-9. Available from: https://www.ncbi.nlm. nih.gov/pmc/articles/PMC5694973/

10. Goolsarran N, Hamo CE, Lane S, Frawley S, Lu WH. Effectiveness of an interprofessional patient safety team-based learning simulation experience on healthcare professional trainees. BMC Medical Educ [Internet]. 2018 [cited 2019 Jun 20];18(1):192-99. Available from: https:// bmcmededuc.biomedcentral.com/articles/10.1186/s12909-018-1301-4 